\title{
DEVELOPMENT OF STUDENTS' VALUE ATTITUDE TO THEIR OWN HEALTH IN THE PROCESS OF PHYSICAL EDUCATION UNDER QUARANTINE
}

\author{
Viktor Koryahin $^{1 \mathrm{ABCD}}$, Oksana Blavt ${ }^{1 \mathrm{ABCD}}$ \\ ${ }^{1}$ Lviv Polytechnic National University \\ Authors' Contribution: A - Study design; B - Data collection; C - Statistical analysis; D - Manuscript Preparation; E - Funds Collection
}

DOI: $10.17309 /$ jltm.2021.2.01

\begin{abstract}
Purpose: identification of the effectiveness of physical education by means of remote technologies for the development of students' value attitude to their own health in the conditions of quarantine restrictions.

Materials and methods. The study involved 3,726 first-year students of the Lviv Polytechnic National University of all educational-and-scientific institutes. Research methods at theoretical and empirical levels were used to solve the tasks. At the theoretical level, general scientific methods were used (analysis, systematization, generalization). At the empirical level of the study, a questionnaire was used.

Results. According to a one-year ascertaining experiment, $30 \%$ of students consider improving and strengthening of their health as a medical problem that is limited to treatment only. Nevertheless, $70 \%$ of respondents believe that it is possible to positively affect their health in the following ways: prevention of diseases by means of physical education (21\%), promoting a healthy lifestyle (21\%), setting up for "healthy" behavior by means of physical education (24\%). When asked whether distanced physical education classes contribute to the development of value attitudes towards their health, the vast majority of students ( $81 \%$ of respondents) claimed that in this way they received new information that they consider useful for maintaining and improving their health.

Conclusions. According to the results of the study, it was established that physical education by means of distance technologies contributes to the development of students' understanding of the need for physical culture, especially in the context of the introduction of quarantine restrictions in higher education institutions. According to the results obtained, the vast majority of students believe that physical education, by means of distance technologies is effective in developing a valued attitude to their own health.

Keywords: physical education, student, health, healthy lifestyle, distance technology, quarantine.
\end{abstract}

\section{Introduction}

Reforming higher education, the positions of which are reflected in the normative and legal documentation (National Report on the State and Prospects of Education in Ukraine (2016), which is the basis of its development in Ukraine, requires radical changes in all levels of the educational process of higher education and the need for its harmonization with world standards in the context of current trends in the development of the industry (Koryahin, Blavt, Vanivska, \& Stadnyk, 2020). The current conditions of globalization and Ukraine's orientation towards the European Community determine the need to solve one of the important tasks of the state policy in the field of education - ensuring the formation of a healthy personality (Ivashchenko, Muszkieta, \& Potop, 2020).

In the higher education system, the task of health preservation is entrusted to the discipline "Physical Education", as

(c) Koryahin, V., Blavt, O., 2021. is stated in the national doctrine of education development. Strengthening and maintaining good health is a priority of the main legislative acts and regulations on physical culture (Kashuba, Futorny, \& Andreyeva, 2012). Thus, in the concept of physical education, in the target comprehensive program "Physical Education - Health of the Nation", the Law of Ukraine "On Physical Culture and Sports" states that physical culture and sports, which are part of the general culture, contribute to the training of students, increasing their mental and physical performance (Zelenskyi, \& Zelenskyi, 2018).

Due to changes in the model of functioning in society, caused by the quarantine restrictions and the benefits of sedentary lifestyle, full of stressful situations and bad habits, the problem of students' health becomes global (Gallo, Gallo, Young, Moritz, \& Akison, 2020).

The only possible answer to the challenges of today's negative tendencies is an immediate solution to the problem situation. The above involves the search for new approaches and methods of interaction with students, forms, methods and 
means of physical education to enable their health preservation and preventing the phenomena of social maladaptation while the quarantine restrictions are applied.

The issue of developing the students' value attitude to the own health is highlighted in this research (Altavilla, 2016; Biktagirova, \& Kasimova, 2016; Kensytska, 2017). The problem is quite timely, since there are negative trends indicating a decrease in the level of health of students in Ukraine (Bergier, Tsos, \& Bergier, 2014; Martyniv, 2013). Researchers point (Deasy, Coughlan, Pironom, Jourdan, \& Mcnamara, 2014; Jiménez-Pavón, Carbonell-Baeza, \& Lavie, 2020) to the fact that quarantine restrictions mean that students have always been in a state of stress in recent years, as mental activity is associated with emotional stress .

At the same time, health care is one of the most difficult problems of physical education in the conditions of distance learning (Bezgrebelna, Pavlos, Bulatov, \& Nezgoda, 2020), which needs to be addressed and solved. In this context, the issue of the content of physical education and the development of its forms, as a mechanism for solving current problems, given the situation related to the distance learning in higher education institutions, is increasingly becoming the subject of scientific attention.

However, despite the interest of scientists in the development of students' value attitude to their own health (Nosov, 2014; Palichuk, 2014; Sigmundová, Chmelík, Sigmund, Feltlová, \& Frömel, 2013), this problem remains insufficiently studied at the theoretical and practical levels in the context of distance education. Taking into account the fact that the development of value attitude to one's own health is an urgent requirement of today, and distance education in the country reflects the objective reality, there is a need to study and understand the results of the influence of physical education by distance learning technologies on the development of students' value attitude to their own health.

The purpose of the study was to identify the effectiveness of physical education by means of distance technologies for the development of students' value attitudes towards their own health in the conditions of quarantine restrictions.

\section{Materials and methods}

Research methods at theoretical and empirical levels were used to solve the tasks. In particular, general scientific methods (analysis, systematization, generalization) were used to study the state of the researched problem according to the information of literature sources; sociological (written survey) - in order to identify problems in the research area, to obtain data on the impact of the discipline "Physical Education" by means of distance technologies on students' understanding of the problems of health preservation; about the peculiarities of motivating students to physical activity, priorities about its types; development of value attitude towards one's own health under quarantine restrictions; the interview was used as an additional method of obtaining the necessary information or explanations to clarify the actual material received during the survey; methods of mathematical statistics - at the stage of data processing for the presentation of the results of pedagogical research, which allowed to carry out quantitative and qualitative analysis of a set of empirical indicators.
At the theoretical level, in particular, the method of analysis and synthesis is used to consider the research issues at the intersection of physical education, education and interdisciplinary research to use data for analyzing the relationships between pedagogical practices and learning outcomes).

The written survey in the form of a questionnaire took place in the indirect interaction of the respondents. The respondents were students. The expediency of using a written survey is justified by the need to obtain actual data, to determine the attitude of the respondents to a certain problem and to evaluate the studied phenomena. The questionnaire was built on a simplified program, with a small amount of tools.

\section{Study participants}

The study involved 3,726 first-year students of the Lviv Polytechnic National University of all educational-and-scientific institutes.

\section{Study organization}

The organization of the study provided that an important condition for ensuring the effectiveness of physical education by means of distance technologies in order to make informed management decisions to ensure the development of students' value attitude to their own health under quarantine restrictions is the availability of prompt and reliable information on the current results.

The organization, conduct and evaluation of the survey was carried out to timely identify and eliminate negative factors and to develop measures to increase the effectiveness of the development of students' value attitude to their own health under quarantine restrictions. In view of this, monitoring provides timely and high-quality data on the results obtained.

Therefore, the survey was carried out using a questionnaire. The expediency of its use is justified by the fact that the advantage of this method is the possibility of obtaining the characteristics of the phenomenon under study. The latter, in turn, are the basis for identifying causal relationships. In addition, the questionnaire allows involving a large number of students in the study, which makes it possible to minimize atypical manifestations. At the same time, it was no personal contact with the respondents.

An email questionnaire was used in the study. The questionnaire is a set of questions, each of which is logically related to the central task of the study. The respondents filled in the questionnaire independently. Compiling the questionnaire involved the transfer of the main hypotheses of the study to the language of questions. Herewith, we tried to make the questionnaire as clear and easy to fill as possible. The questions were specially selected, carefully thought out in advance and pre-tested on a small group of test subjects (5-20 people). The time to complete the questionnaire was within $45 \pm 10$ minutes.

\section{Statistical analysis}

Methods of mathematical statistics were used to analyze the sets of empirical data obtained. Statistical processing of the data was carried out on a computer using the standard STATISTICA 7.0 programs. 


\section{Results}

First, let us clarify that among the determinants who determine the state of health of students under the quarantine restrictions and the transition of higher education institutions to the distance education, the lifestyle is primarily distinguished (Jiménez-Pavón, Carbonell-Baeza, \& Lavie, 2020). Nevertheless, we fancy the idea (Tucker, \& Irwin, 2011), that the state of health also depends on whether one's own health is of value for oneself.

Modern scientific research convincingly proves that human health is of individual value (Altavilla, 2016; Ivanova, 2020; Kumar, \& Preetha, 2012). Numerous empirical studies have shown that physical culture and a healthy lifestyle can minimize and sometimes eliminate the risk of bad state of health or illness (Haase, Steptoe, Sallis, \& Wardle, 2004; Kolb, \& Kolb, 2005; Wigger, 2010).

It is worth noting that in the process of determining the concept of "health", researchers distinguish such components as physical, psychological, behavioral health (Australian Curriculum, Assessment and Reporting Authority, 2012). Emphasizing the special importance of motivation to maintain health and psychological-and-pedagogical conditions necessary to ensure the effectiveness of a healthy lifestyle of students and the development of value attitudes of their own health (Bray, \& Born, 2004; Höner, \& Demetriou, 2014).

In our study, we positioned physical education by means of distance technologies as a tool for developing of students' value attitudes toward their own health. This implied that it is a pedagogical process aimed at eliminating the existing negative tendencies in their physical development and health by means of physical education on the body systems by stimulating this activity, taking into account the specifics of the situation caused by the pandemic.

The introduction in the educational process of the need for the development of value attitude to one's own health required the modeling of an effective educational environment to create a stereotype of health-preservation, and given the unity of physical and neuropsychological development - an improvement of the relevant indicators. Therefore, this implied a combined effect during physical education classes on the cognitive and motor areas of students.

Thus, according to the one-year ascertaining experiment, the following was established. $30 \%$ of respondents consider improvement and strengthening of health as a medical problem, which boils down only to the treatment of diseases (Fig. 1). Instead, $70 \%$ of respondents believe that it is possible to

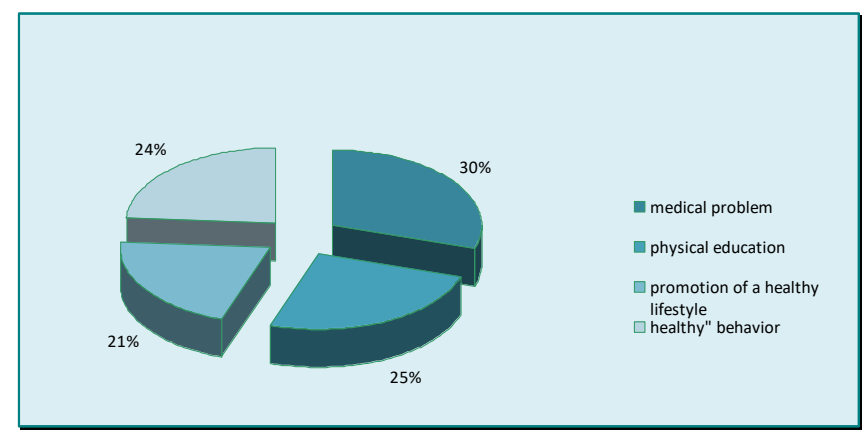

Fig. 1. Place of the concept of "health" as one of the important components in the system of values of students influence positively the health of students in the following ways: prevention of diseases by means of physical education (21\%), promotion of a healthy lifestyle (21\%), setting up for "healthy" behavior by means of physical education (24\%).

However, not all students, according to the survey results, are sufficiently informed about a healthy lifestyle, and some of them deliberately neglect it. Instead, the vast majority of them believe that leading a healthy lifestyle is important for everyone and especially now for students, because it is students who are on distance learning for a long time.

It is believed that physical education classes contributed to obtaining knowledge about a healthy lifestyle, namely, $72.4 \%$ of respondents understood that person's health not only includes the physical, mental and social existence of a person, but also takes into account his beliefs, expectations and worldview (Fig. 2). At the same time, $27.6 \%$ of students associate a healthy lifestyle with health that is based on subjective and objective assessment of his physical and social activity. Thus, most students do not have sufficient knowledge about the benefits of motor activity for the human body. Lack of interest in regular physical education classes leads to a decrease in the health and physical condition of young people.

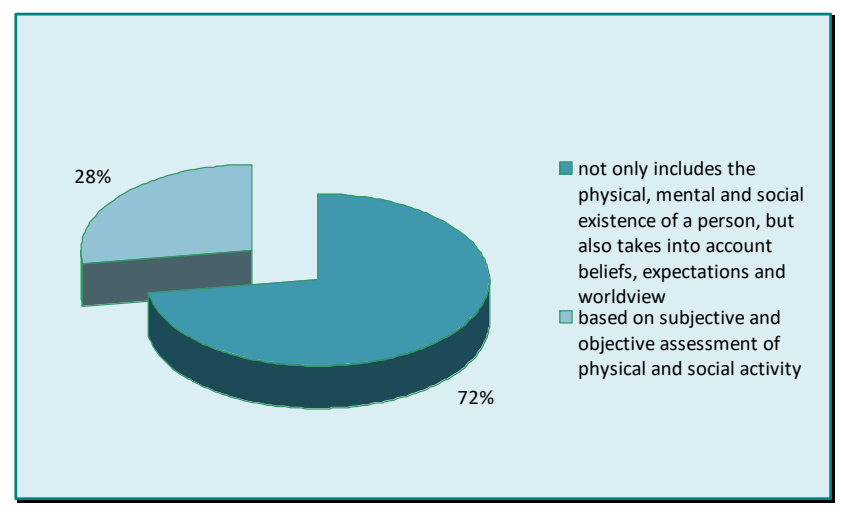

Fig. 2. The state of students' awareness about a healthy lifestyle

It was found that students invest in the concept of "health preservation": the harmonious combination of work and rest (22.3\%), the optimal nutrition (15.2\%), the systematic physical activity (51.6\%), the hygiene (6.3\%), the absence of bad habits $(17.2 \%)$, the positive emotions (71.2\%); the intellectual development (73.2\%); the moral and spiritual development (32.3\%); the formation and development of volitional qualities (14.2\%), as well as the friendly attitude to others and to life in general in all its manifestations (42.3\%).

$91.4 \%$ of students understand the need for practical actions aimed at developing a value attitude to their own health, preventing diseases, strengthening of all body systems and improvement of overall well-being. At the same time, 55.4\% of respondents say that their health has deteriorated during the year, others that they have the highest working capacity and easily perform daily tasks of varying complexity. $65.4 \%$ of respondents say that physical health significantly hinders vigorous action, a third of respondents cannot study effectively due to physical health problems.

When asked whether distance physical education classes contribute to the development of value attitudes towards their health, the vast majority of students ( $81 \%$ of respondents) claimed that in this way they received a new informa- 


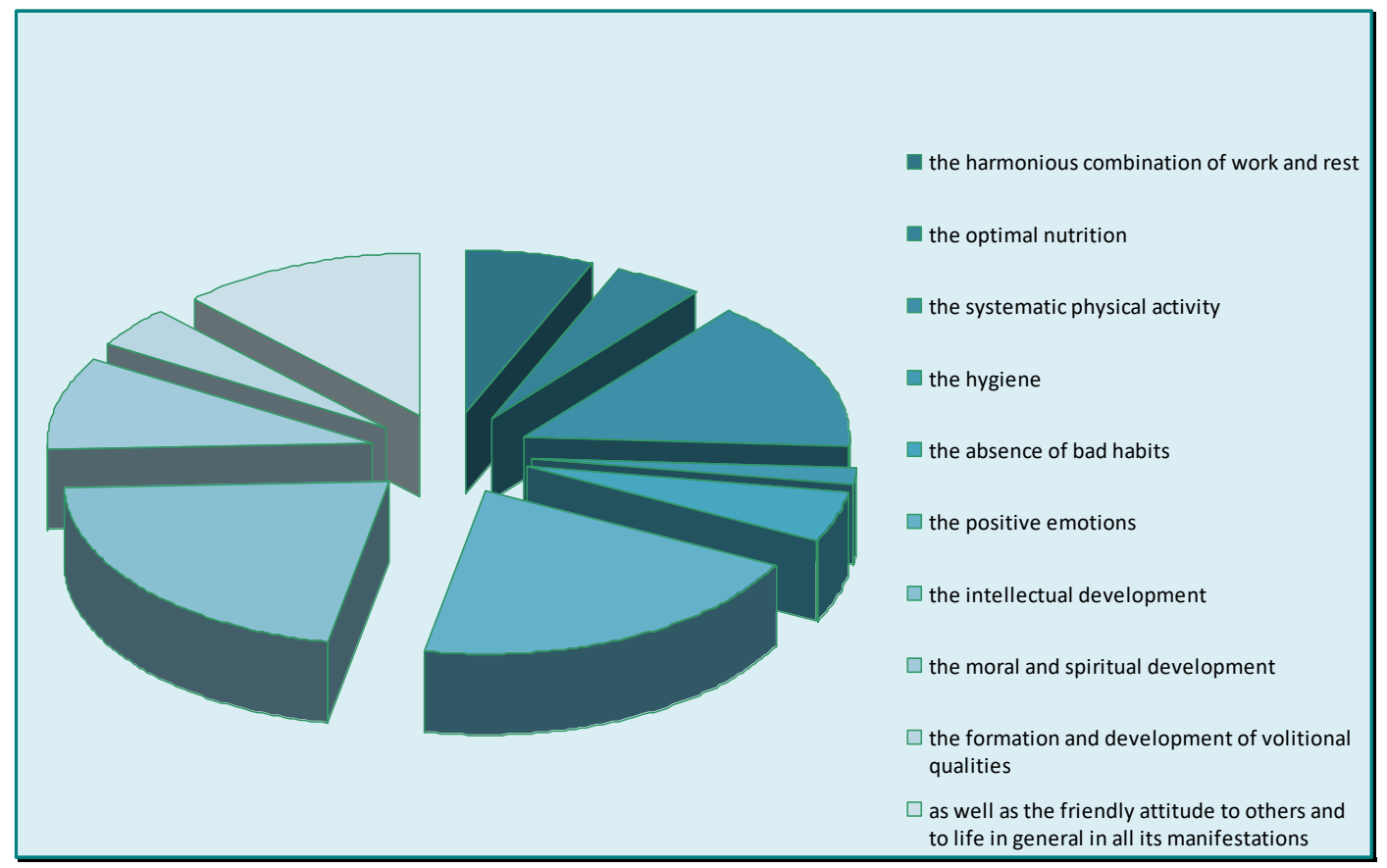

Fig. 3. The concept of "health preservation" in the understanding of students

tion. As a result of the survey, we concluded that students try to follow a healthy lifestyle and we identified the main factors for ensuring it. As a result, $77 \%$ of respondents try to adhere to a healthy lifestyle from time to time, only $12 \%$ of respondents always adhere and $11 \%$ of respondents do not care about health problems at all.

$68.7 \%$ of respondents noted an increase in the level of motor activity in their free time based on the knowledge gained in physical education classes, $9.2 \%$ of students showed no changes in lifestyle, $82.1 \%$ of respondents showed a decrease in the level of daily motor activity due to the quarantine restrictions. Nonetheless, $72.3 \%$ of the students surveyed are ready for the personal health-preservation. The latter was considered as an integrated concept of education and development of value attitude to one's own health, motivation for health-preservation and an adequate understanding of one's own state of health. Priority motives for physical education as a factor in the development of value attitude for one's own health were identified. In the first place, there is a motive "Maintaining and improving body shape" (45.7\%). According to the frequency of selected answers, the second place is the motive "Preserve one's health" (36\%). On the third place was the motive "Development of one's physical condition" (12.7\%). The least priority motive for exercise is "Reduction of excess body weight", it was chosen by only $5.2 \%$. Therefore, it was found that for the vast majority of students the latter factor is not significant.

\section{Discussion}

Our research is based on the fact that caring attitude to one's own health is a very important issue in modern society, because health is considered a social value (Palichuk, 2014). Among the main tasks of higher educational institutions are solving the problem of supporting and strengthening the health of students, creating a health atmosphere in the system of their education (Kashuba, Futorny, Andreyeva, 2012;
Sukys, Majauskiene, \& Dumciene, 2017). In scientific sources, the issue of supporting and improving the health of future professionals as the main driver of progress in all spheres of society and the state today is positioned by the scientists as a one of the most pressing (Bergier, Tsos, \& Bergier, 2014; Biktagirova, \& Kasimova, 2016).

The study expands the scientific data that an important factor in the formation of a culture of students' health during studying in higher education institutions is the system of physical education (Buultjens, \& Robinson, 2011; César, Zaia, Trevisan, Garzon, Laganà, \& Montagna, 2020). According to the latest trends (Kensytska, 2017), higher education institutions require "the development of a new model of motivating student youth to a healthy lifestyle, physical culture and sports, in accordance with the realities of modern Ukrainian society." Research in this area has been constantly carried out in the field of physical education. However, the realities of today require effective action on this. Therefore, we agree that focusing on the health-preservation of students in distance education is a complex and multifaceted process (Bezgrebelna, Pavlos, Bulatov, \& Nezgoda, 2020). This is especially true on the most vulnerable segment of the population - students, whose health problem today, more than ever, is relevant, and the way to solve it is extremely necessary to consider first of all in the educational sphere. Undoubtedly, the formation of readiness of students for health-preserving activity is considered as one of the results of physical education in the system of higher education (Ivashchenko, \& Khudolii, 2011; Palichuk, 2014).

Scientific studies convincingly prove that during the 2019/2020 academic year there was a decrease in physical activity of students. In 2020, the situation became more complicated due to the implementation of quarantine measures caused by the significant spread of acute respiratory disease COVID-19. We support the idea that such a situation requires radical changes and modernization of approaches to the implementation of physical education in order to en- 
sure the effectiveness of its goals (Jiménez-Pavón, CarbonellBaeza, \& Lavie, 2020; Raiola, Aliberti, Esposito, Altavilla, D’Isanto, D’Elia, 2020).

We agree with the opinion (Bray, \& Born, 2004; Biktagirova, \& Kasimova, 2016; Martyniv, 2013), that solving the problem of health-preservation for students of higher education institutions is important to develop such tools for the implementation of physical education by means of distance technologies, which would ensure the formation of a responsible attitude of each student to personal health. In this aspect, the idea that the psychological component in this process also plays a very important role is also used (Deasy, Coughlan, Pironom, Jourdan, \& Mcnamara, 2014; Extremera, \& Fernández-Berrocal, 2006).

Our study expands the ideas about the goals of physical education in the conditions of forced self-isolation of students (Bezgrebelna, Pavlos, Bulatov, \& Nezgoda, 2020). It is consistent with the opinion (Gallo, Gallo, Young, Moritz, \& Akison, 2020) on the need to acquire healthy lifestyle skills as a component of preserving and strengthening the health of students, to adhere to a healthy lifestyle, forming the need for physical self-improvement.

Given the changes in the educational process, the issue of introducing the latest methods of physical education is updated, which causes the justification and development of a distance learning system in a discipline aimed at developing a value attitude to one's own health under quarantine restrictions. The study of domestic and foreign scientific works on physical education suggests that one of the main conditions for the qualitative development of value attitude to one's own health is the practical orientation of the educational process (Ivanova, 2020; Makopoulou, \& Armour, 2011).

We believe that this approach makes it possible to carry out holistic physical education by means of distance technologies as a social, educational phenomenon of physical education. The anticipated result of which should be the personal development of the student and the increase in the level of development of value attitude to their own health in the conditions of quarantine restrictions, students' self-realization and personal growth.

The creation of a new educational space requires the introduction of forms and methods of organizing this process by means of distance technologies. The latter is considered as a modern educational environment, comfortable, safe and convenient for all participants in physical education, which has all the potential for ensuring the effectiveness of the physical education process.

Undoubtedly, this involves the development of methodological recommendations for conducting physical education classes with innovative approaches at home during quarantine and other conditions that limit the use of gyms in educational institutions, sports clubs and playgrounds. Now technologies are developing so rapidly that teachers desperately need tools that to adapt the knowledge of professionals to the challenges facing the educational process of physical education in higher education institutions.

\section{Conclusions}

Due to changes in the model of functioning in society caused by the implementation of quarantine restrictions and the benefits of sedentary lifestyle, full of stressful situations and bad habits, the problem of students' health is gaining global importance. This question forces us to look constantly for new ways to motivate young people to exercise in order to develop a valued attitude to their own health.

According to the results of the study, it was established that the physical education of students by means of distance technologies contributes to the development of understanding of the need for physical culture, especially in the context of the introduction of quarantine restrictions in higher education institutions. According to the results obtained, the vast majority of students believe that physical education by means of distance technologies is effective in developing an understanding of a healthy lifestyle and value attitude to their own health.

The processing of the results obtained during the questionnaire gives the basis for the conclusion that the task of maintaining, preserving and strengthening the health of student youth requires attention and development of a system of measures based on the use of the potential of the academic environment of the higher education institution, including the means of physical education. This provides an information, training and education aimed at the acquisition of knowledge, the formation and development of skills and abilities to lead a healthy lifestyle, the development of value attitude to one's own health in all its manifestations.

The practical significance of the results of the research is the basis for the development of scientific and methodological recommendations for their implementation in the practice in educational institutions, in the context of strategic areas of physical education of students.

\section{Conflict of interest}

The authors state no conflict of interest.

\section{References}

Koryahin, V., Blavt, O., Vanivska, O., \& Stadnyk, V. (2020). Potential of new technologies in providing efficiency of pedagogical control in physical education. Theory and Methods of the Physical Education, 20(1), 25-31.

https://doi.org/10.217309/tmfv.2020.1.04

Ivashchenko, O., Muszkieta, R., \& Potop, V. (2020). Didactics: Methodological Approaches to Determining the Content of Physical Education Teacher Training. Journal of Learning Theory and Methodology, 1(1), 40-47. https://doi.org/10.17309/jltm.2020.1.06

Kashuba, V.A., Futorny, S.M., \& Andreyeva, E.V. (2012). Analysis of using health preserving technologies in the process of physical education of student youth. Teoriya $i$ metodyka fizkultury, 1, 73-81. (in Ukrainian)

Zelenskyi, B., \& Zelenskyi, R. (2018). Motivation: Attitude of Students of Higher Education Institutions of the III Accreditation Levels Toward Physical Education Classes. Teoriâ ta Metodika Fizičnogo Vihovannâ, 18(3), 114-125. https://doi.org/10.17309/tmfv.2018.3.02 (in Ukrainian)

Gallo, L.A., Gallo, T.F., Young, S.L., Moritz, K.M., \& Akison, L.K. (2020). The impact of isolation measures due to COVID-19 on energy intake and physical activity levels in Australian university students. Nutrients, 12(6), 1865. https://doi.org/10.3390/nu12061865 
Altavilla, G. (2016). Relationship between physical inactivity and effects on individual health status. Journal of Physical Education and Sport, 2, 1069-1074.

https://doi.org/10.7752/jpes.2016.s2170

Biktagirova, G.F., \& Kasimova, R.Sh. (2016). Formation of University Students' Healthy Lifestyle. International Journal of Environmental and Science Education, 11(6), 1159-1166. https://doi.org/10.12973/ijese.2016.385a

Kensytska, I. (2017). Model of formation of values of a healthy way of life of students in the course of physical education. Theory and Methods of the Physical Education and Sports, 4, 69-76. https://doi.org/10.32652/tmfvs.2017.4.69-76 (in Ukrainian)

Bergier, B., Tsos, A., \& Bergier, J. (2014). Factors determining physical activity of Ukrainian students. Annals of Environmental Medicine, 21(3), 613-616. https://doi.org/10.5604/12321966.1120612

Martyniv, O. (2013). Analysis of students' readiness for a healthy lifestyle as an indicator of a culture of health. Scientific Bulletin of Uzhhorod National University. Series: Pedagogy. Social Work, 28, 100-103. (in Ukrainian)

Deasy, C., Coughlan, B., Pironom, J., Jourdan, D., \& Mcnamara, P. M. (2014). Psychological distress and lifestyle of students: implications for health promotion. Health promotion international, 30(1), 77-87. https://doi. org/10.1093/heapro/dau086

Jiménez-Pavón, D., Carbonell-Baeza, A., \& Lavie, C.J. (2020). Physical exercise as therapy to fight against the mental and physical consequences of COVID-19 quarantine: Special focus in older people. Physical Progress in Cardiovascular Diseases, 63(3), 386-388.

https://doi.org/10.1016/j.pcad.2020.03.009

Bezgrebelna, O.P., Pavlos, R.M., Bulatov, O.M., \& Nezgoda, S.P. (2020). Activation of innovative means of physical education of students of higher education institutions. Scientific Journal of the National Pedagogical University M.P. Name MP Drahomanov. Series 15: Scientific and pedagogical problems of physical culture (physical culture and sports), 5(125), 21-25.

https://doi.org/10.31392/npu-nc.series15.2020.5(125).03 (in Ukrainian)

Nosov, A.G. (2014). Diagnosis of the level of formation of healthy lifestyle among students. Modern problems of science and education, 12(12), 2644-2648. (in Ukrainian)

Palichuk, Yu.I. (2014). The model of health care in the educational process of higher economic school. Pedagogical sciences: theory, history, innovative technologies, 6(40), 230-236. (in Ukrainian)

Sigmundová, D., Chmelík, F., Sigmund, E., Feltlová, D. \& Frömel, K. (2013). Physical activity in the lifestyle of Czech university students: Meeting health recommendations. European Journal of Sport Science, 13(6), 744-750. https:// doi.org/10.1080/17461391.2013.776638

Tucker, P., \& Irwin, J.D. (2011). University Students' Satisfaction With, Interest in Improving, and Receptivity to Attending Programs Aimed at Health and Well-Being. Health Promot Pract, 12, 388-395. https://doi.org/10.1177/1524839908330814

Ivanova, N.L. (2020). Physical education classes as a way of forming value orientations in the educational space of surgut oil and gas institute. Journal of Critical Reviews, 7(1), 317-319. http://dx.doi.org/10.31838/jcr.07.01.61
Kumar, S., \& Preetha, G.S. (2012). Health Promotion: An Effective Tool for Global Health. Indian Journal of Community Medicine, 37(1), 5-12.

Haase, A., Steptoe, A., Sallis, J.F., \& Wardle, J. (2004). Leisure-time physical activity in university students from 23 countries: Associations with health beliefs, risk awareness, and national economic development. Preventive Medicine, 39(1), 182-190. https://doi.org/:10.1016/j.ypmed.2004.01.028

Kolb, A.Y., \& Kolb, D.A. (2005). Learning Styles and Learning Spaces: Enhancing Experiential Learning in Higher Education. Academy of Management Learning \& Education, 4, 193-212. https://doi.org/10.5465/amle.2005.17268566

Wigger, U. (2010). Exercise and youth: Physical activity,sport involvement, and development. European Journal of Sport Science, 1(3), 1-8. https://doi.org/10.1080/17461390100071305

Australian Curriculum, Assessment and Reporting Authority (2012). ACARA Copyright Administration, ACARA Level 10, 255 Pitt Street Sydney NSW 2000

Bray, S.R., \& Born, H.A. (2004). Transition to university and vigorous physical activity: Implications for health and psychological well-being. Journal of American College Health, 52(4), 181-188. https://doi.org/10.3200/JACH.52.4.181-188

Höner, O. \& Demetriou, Y. (2014). Effects of a healthpromotion programme in sixth grade German students' physical education. European Journal of Sport Science, 14(1), S341-S351. https://doi.org/10.1080/17461391.2012.704080

Sukys, S., Majauskiene, D. \& Dumciene, A. (2017). The effects of a three-year integrated Olympic education programme on adolescents' prosocial behaviours. European Journal of Sport Science, 17(3), 335-342. https://doi.org/10.1080/17461391.2016.1254280

Biktagirova, G.F., \& Kasimova R.Sh. (2015). Development of University Students' Creative Abilities. Review of European studies, 7(5), 101-107. https://doi.org/10.5539/res.v7n5p101

Buultjens, M., \& Robinson, P. (2011). Enhancing aspects of the higher education student experience. Journal of Higher Education Policy and Management, 33(4), 337-346. https://doi.org/:10.1080/1360080X.2011.585708

César, J.N., Zaia, V., Trevisan, C.M., Garzon, S., Laganà, A.S., \& Montagna, E. (2020). Attitudes and Values of Physical Education Professionals and Undergraduate Students about Their Role in Health Promotion. Int J Environ Res Public Health, 17(7), 2288.

https://doi.org/10.3390/ijerph17072288

Ivashchenko, O.V., \& Khudolii, O.M. (2011). Discipline "General foundations of the theory and methods of physical education". Evaluation criteria. Message II Theory and methods of physical education, 12, 19-34.

http://www.tmfv.com.ua/journal/article/view/758 (in Ukrainian)

Raiola, G., Aliberti, S., Esposito, G., Altavilla, G., D'Isanto, T., D'Elia, F. (2020). How has the Practice of Physical Activity Changed During the COVID-19 Quarantine? A Preliminary Survey. Teoriâ ta Metodika Fizičnogo Vihovannâ, 20(4), 242-247. https://doi.org/10.17309/tmfv.2020.4.07 
Extremera, N., \& Fernández-Berrocal, P. (2006). Emotional intelligence as predictor of mental, social, and physical health in university students. Spanish Journal of Psychology, 9(1), 45-51. https://doi.org/10.1017/s1138741600005965
Makopoulou, K., \& Armour, K. (2011). Teachers' professional learning in a European learning society: The case of physical education. Phys. Educ. Sport Pedagog, 16, $417-$ 433. https://doi.org/10.1080/17408989.2010.548060

\title{
РОЗВИТОК ЦІННІСНОГО СТАВЛЕННЯ ДО ВЛАСНОГО ЗДОРОВ'Я СТУДЕНТІВ В ПРОЦЕСІ ФІЗИЧНОГО ВИХОВАННЯ В УМОВАХ КАРАНТИНУ
}

\author{
Віктор Корягін ${ }^{1 \mathrm{ABCD}}$, Оксана Блавт ${ }^{1 \mathrm{ABCD}}$ \\ ${ }^{1}$ Національний університет «Львівська політехніка» \\ Авторський вклад: А - дизайн дослідження; В - збір даних; C - статаналіз; D - підготовка рукопису; Е - збір коштів \\ Реферат. Статья: 7 с., 3 рис., 33 джерела.
}

Мета дослідження - виявлення ефективності фізичного виховання засобами дистанційних технологій на розвиток у студентів ціннісного ставлення до власного здоров'я в умовах карантинних обмежень.

Матеріали і методи. У дослідженні взяли участь 3726 студентів першого курсу Національного університету «Львівська політехніка» всіх навчально-наукових інститутів. Для вирішення поставлених завдань використовували методи дослідження на теоретичному та емпіричному рівнях. На теоретичному рівні було використано загальнонаукові методи (аналіз, систематизація, узагальнення). На емпіричному рівні дослідження використовували анкету

Результати. За даними однорічного констатувального експерименту встановлено, що $30 \%$ студентів розглядають покращення і зміцнення свого здоров'я як медичну проблему, яка зводиться лише до лікування. Натомість, 70\% опитаних вважають, що можна позитивно вплинути на стан свого здоров'я такими способами: профілактикою захворювань засобами фізичного виховання (21\%), пропагандою здоро- вого способу життя (21\%), налаштування на «здорову» поведінку засобами фізичного виховання (24\%). На питання анкети, чи заняття з фізичного виховання у дистанційному форматі сприяють розвитку ціннісного ставлення до свого здоров'я переважна більшість студентів (81\% опитаних) стверджувала, що таким шляхом вони отримали нову для себе інформацію, яку вважають корисною задля збереження та покращання свого стану здоров’я.

Висновки. За результатами здійсненого дослідження, установлено, що фізичне виховання засобами дистанційних технологій сприяє розвитку розуміння у студентів необхідності занять фізичною культурою, особливо в умовах упровадження карантинних обмежень у закладах вищої освіти. Згідно отриманим підсумкам, переважна більшість студентів вважає фізичного виховання засобами дистанційних технологій ефективним у розвитку ціннісного ставлення до власного здоров'я.

Ключові слова: фізичне виховання, студент, здоров'я, здоровий спосіб життя, дистанційні технології, карантин.

\section{Information about the authors:}

Koryahin V.: koryahinv@meta.ua; https://orcid.org/0000-0003-1472-4846; Department of Physical Education, Lviv Polytechnic National University, Bandera St, 12, Lviv, 79013, Ukraine.

Blavt O.: oksanablavt@ukr.net; https://orcid.org/0000-0001-5526-9339; Department of Physical Education, Lviv Polytechnic National University, Bandera St, 12, Lviv, 79013, Ukraine.

Cite this article as: Koryahin, V., \& Blavt, O. (2021). Development of Students' Value Attitude to Their Own Health in the Process of Physical Education Under Quarantine. Journal of Learning Theory and Methodology, 2(1), 53-59.

https://doi.org/10.17309/jltm.2021.2.01

Received: 25.03.2021. Accepted: 05.05.2021. Published: 30.06.2021

This work is licensed under a Creative Commons Attribution 4.0 International License (http://creativecommons.org/licenses/by/4.0). 